\title{
Seeing the forest for the trees: identifying discursive convergence and dominance in complex REDD+ governance
}

\author{
Fariborz Zelli ${ }^{1}$, Tobias D. Nielsen ${ }^{1}$ and Wilhelm Dubber ${ }^{1}$
}

\begin{abstract}
Scholars of international law and international relations largely agree that global governance today, and global environmental governance in particular, is marked by institutional complexity. Environmental policy fields are, to varying degrees, governed by a plurality of institutions with different levels of legalization, membership, and jurisdictional scope, and with different degrees of coherence among them. The international governance architecture on Reducing Emissions from Deforestation and Forest Degradation (REDD+) is a case in point. Located at the intersection of the governance systems on climate change, biodiversity, forestry, and development, REDD+ governance provides a stage where a large variety of intergovernmental and transnational institutions come together, collaborate, or compete on questions of standard-setting, financing, implementation, and evaluation. This complexity poses challenges to the effectiveness of REDD+ governance in general, but also to specific actor groups and organizations that lack the resources to understand and navigate such a fragmented governance landscape. Against this backdrop, we introduce an analytical framework to read and structure a complex governance architecture. The framework breaks new ground by adopting argumentative discourse analysis and the concept of storylines to the study of institutional complexity. We argue that beyond the messy surface of institutional complexity there may be a surprising degree of convergence, in the sense of discursive hierarchies that run across institutions, practices, and scales. We illustrate such a cross-cutting hierarchy for the complex REDD+ governance system, focusing on the sensitive issue of forest carbon monitoring. In our analysis of respective guidance documents and country reports, we find, underneath the institutional complexity across governance scales, a considerable dominance of techno-managerial perspectives and a preference for carbon commodification. This discursive hegemony and convergence resonates with the dominance of certain REDD+ funding institutions and the prioritization of the monitoring practice of remote sensing.
\end{abstract}

Key Words: discourse analysis; institutional complexity; institutional fragmentation; monitoring; MRV; national forest inventory; $R E D D+$; regime complex; remote sensing; safeguards

\section{INTRODUCTION AND RATIONALE}

Institutional complexity has been increasingly accepted and scrutinized as an inherent structural characteristic of global environmental governance today, and this by a variety of scholarships ranging from international law and international relations to human geography and environmental studies (cf. Lubell et al. 2014). They share the assumption that this complexity matters in crucial ways for the equity and effectiveness of environmental governance processes (Folke et al. 2007, Ekstrom and Young 2009). For instance, more institutions, networks, and processes may offer more platforms for inclusion, but they may also add to coordination gaps (Biermann et al. 2009, Zürn 2018).

REDD+ governance is a case in point. Located at the intersection of the governance systems on climate change, biodiversity, forestry, and development, REDD+ provides a nexus where a large variety of institutions from these different fields come together, collaborate, or compete. The result is a complex governance system in its own right, marked by the proliferation of intergovernmental and transnational institutions for standardsetting, financing, implementation, and evaluation (Gupta et al. 2016). This complexity may disadvantage in particular those stakeholders with less-developed organizational or financial capacities because they are ill-equipped to keep track of, participate in, or benefit from the plurality of institutions and discussions.

Most of the analytical frameworks on institutional complexity are conceptual and typological in nature and do not help us to identify such implications. What is largely missing are substantial theoretical approaches that grasp underlying drivers or conditions of a complex architecture. Various authors began to address this theoretical gap and showed that we do not need to reinvent the wheel for this purpose. They adopted extant theories for their frameworks, such as neoliberal institutionalism (Van de Graaf 2013, Morse and Keohane 2014), functionalist approaches and sociological differentiation theory (Gehring and Faude 2013, Zürn and Faude 2013), theories on private authority and transnational actors (Green 2014), and tenets of organizational ecology (Abbott et al. 2016). In this article, we turn to discourseanalytical approaches, a realm of theories that until present has remained largely unexplored for the study of institutional complexity.

Our objective is twofold. First, we introduce a discourseanalytical framework on institutional architectures or complexes (Raustiala and Victor 2004), i.e., sets of public and private institutions, often only loosely coupled, that regulate a particular issue area of multilevel governance. Concretely, we build our framework on the tradition of argumentative discourse analysis (Hajer 1995, 2006). This framework enables us to "read" governance architectures, including very complex ones, by identifying underlying discourses that may imply more hierarchy and convergence than a mere look at the institutional patchwork would reveal. We hold that a core notion of the argumentativediscursive approach, on the mutual constitution of institutions with discourses and practices, can also be applied to institutional complexes as a whole. In other words: there is an interdependence 
between (1) the institutional hierarchies in a global governance architecture, (2) prevailing governance practices therein, and (3) dominant discourses underlying this architecture.

Our second goal is to illustrate the benefits of such a discursive lens for the case of complex REDD+ governance. We explore our framework for a sensitive issue in the REDD+ debate: the design and practices of monitoring forest carbon changes. Forest governance, and REDD+ in particular, have come under increasing scrutiny in discursive analyses that show how certain overarching storylines are emerging across political levels and forest regions (Bäckstrand and Lövbrand 2006, Arts and Buizer 2009, Wallbott 2014, Milne et al. 2016, Ochieng et al. 2016a, b). Bringing these insights together with the problem of institutional complexity, we ask which discursive storylines are coconstituted with the fragmented institutional landscape on REDD+ and which of these are dominant in REDD+ monitoring. We analyze perspectives on forest carbon monitoring in guidance documents of multilateral financing institutions and in reports of selected countries to these institutions. Our findings show that, underneath the institutional diversity on REDD+ monitoring, there is a considerable dominance of techno-managerial perspectives and carbon commodification views, while community-based and participatory elements are of marginal importance. This discursive hegemony resonates with the dominance of specific institutions and the monitoring practice of remote sensing.

At the heart of this article is, thus, the connection between discourses, institutions, and practices, and their respective hegemonic patterns. That said, there is also a fourth level that resonates with these patterns, namely the hierarchy and power relations among actor groups that are associated with stronger or weaker institutions and discourses. Although the scope of our analysis did not allow us to include this actor dimension systematically, we frequently refer to this connection in the article, e.g., to the marginalization of community-based monitoring.

\section{CONCEPTUAL AND ANALYTICAL FRAMEWORK}

\section{Argumentative discourse analysis}

The many organizations, governance instruments, and actors in the complex REDD+ governance system rely on different ideas that they attach to the loss of forests and to the degradation of ecosystems and livelihood. These different meanings, some evident, others more inconspicuous, inform their rationales and understandings toward REDD + , and hence are an important part of the type of governance structures that emerge and change over time (Yanow 1996, Fisher 2003).

Discourse analysis can reveal such meanings that are not palpable at first glance. We follow a definition of discourse as "a specific ensemble of ideas, concepts, notions and categorizations that are produced, reproduced, and transformed in a particular set of practices and through which meaning is given to physical and social realities" (Hajer 2009:60). Discourses construct meanings, by defining what is legitimate knowledge and setting a limit on the range of responses we have to certain problems (Dryzek 2013). Crucially for our understanding, discourses are not free floating; they are embedded in institutions and play an important role in structuring the relations of power within them (Fairclough 1992).
Several scholars started to theorize this connection between discourses and institutions, their pioneering work often being summarized under the label "discursive institutionalism." However, there are important ontological and epistemological differences within this camp. Scholars like Arts and Buizer (2009) and Schmidt $(2008,2017)$ follow a historical institutionalist and hermeneutic tradition. They acknowledge the impact of path dependencies and societal contexts, but grant actors a certain degree of autonomy to choose language or discourses in order to shape the policy world around them. By contrast, Maarten Hajer is influenced by Foucauldian discourse analysis, defining discourse in a broader manner and emphasizing how discourses and social practices, including institutions, the economy, and power processes, are intertwined. For Hajer, language cannot be isolated from practice, and the former cannot simply be used to rationally or strategically influence the later. We follow Hajer's understanding that the relationship between discourses and institutions is not a one-way street and that institutions, and the practices they promote, can in turn shape discourses (cf. Wagenaar 2011).

Within Hajer's theoretical work, we use a particular approach for the study of institutional complexity: argumentative discourse analysis (ADA; Hajer 1995). ADA aims to unravel the argumentative structures and linguistic regularities in documents and other written or spoken statements as well as the practices through which these utterances are made (Hajer and Versteeg 2005). Language is seen not as a neutral messenger of given interests and preferences, but influences their very formation. Moreover, it enables and limits the range of institutional practices and interactions in which actors can engage (Dryzek 2013). Hajer (2009) went on to further refine his approach by combining discursive methods with dramaturgical ones to study the dynamics and performance of authority across policy levels. The merits of this more comprehensive theory notwithstanding, we here have to suffice with a pragmatic take for a first adoption of his work.

With its focus on documents and statements, ADA gives us such a pragmatic approach to reveal hidden connections across institutions and scales. Moving its arguments from the study of single institutions to the analysis of institutional complexity, we hold that an entire governance architecture is mutually constituted with a discursive structure. The hierarchical (conflictive or synergistic) relations among core institutions, and the preferences for certain types of practices and instruments across this architecture, may reflect the contestation and dominance patterns of underlying discourses. ADA can therefore improve our understanding of any institutional architecture in global or multilevel governance, including very complex ones. Even an at-first glance impenetrable degree of institutional complexity may become readable in an ADA-guided analysis, in terms of discursive storylines, practices and the hierarchy among them.

\section{Storylines and practices in a complex governance architecture}

Being pragmatic also implies that we concentrate our framework and its illustration on two particular conceptual tools of ADA, practices and storylines. Hajer defined storylines in various, closely related ways throughout his work. Here, we follow his understanding of storyline as a "generative sort of narrative that 
allows actors to draw upon various discursive categories to give meaning to specific physical or social phenomena" (Hajer 1995:56). In more pragmatic terms, they are recurring condensed statements that people use as a kind of shorthand in discussions and that summarize more complex discourses (Hajer 2006).

This use of storylines as both proxies and components of wider discourses has two implications for the way we apply them here. First, unlike poststructuralist discourse theories, ADA puts slightly stronger emphasis on actors and their intentionality, acknowledging a mutual constitution among actors and storylines (Hajer and Versteeg 2005). Actors use storylines explicitly, e.g., to refer to certain types of solutions, while, implicitly and unintentionally, drawing on wider discourses, e.g., a (neo-)liberal environmentalism (Bernstein 2002), to give meaning to physical or social phenomena, such as, in our analysis, forest carbon monitoring. Based on this assumption we believe that we can identify storylines in actors' statements and documents on REDD+. Second, seeing storylines on a middle ground between actors and discourses implies that they do not need to have a clear beginning, middle, and end, and in this our framework differs from the storyline concepts of other strands of discursive policy analysis (Kaplan 1986, Roe 1994). Put differently, we will discuss and analyze storylines in their current representation of forest-related discourses, not in their wider development over time.

Whereas storylines are a form through which discourses are articulated, the concept of practice highlights how discourses become manifested. Analyzing practices can therefore also help us to identify the existence or dominance of a discourse, depending on the shape of these manifestations. Although language, and specifically storylines, are a central part of the analysis, the articulation of socially constructed realities does not take place in a social vacuum, but rather in the context of "distinct techniques" and "organizational routines" (Hajer 1995, Wagenaar and Cook 2003). Practice thus opens up for the analysis of discourse beyond mere texts (Neumann 2002). Although we are mindful that practices can be many different things depending on the discourse-analytical perspective, in our illustration we restrict our focus to specific carbon monitoring techniques that are planned in REDD+ programs.

In summary, for our selected case, we expect that certain discourses are underlying the complex REDD+ governance system, that they are articulated in specific storylines, and that they are manifested in different practices of how forest carbon is monitored, by whom, and what the monitoring focuses on. We expect to find such (dominant and) recurring storylines in connection with certain (dominant and) recurring practices across institutions, for instance, when particular documents argue for the use of a certain forest carbon monitoring technique. These documents, in turn, are related to specific (dominant) international institutions, e.g., as guidance documents from REDD+ funding instruments and country reports to these institutions.

\section{Research steps and material}

Given the limited scope of this article, we can only provide an explorative application of the analytical framework to a specific case and with the help of several approximations. Based on the idea of a mutual constitution of institutions, practices, and storylines we introduce these three dimensions in successive steps, with the main analytical focus on storylines.

We begin with two descriptive sections. We identify dominant institutions in the complex REDD+ governance system, and for the issue of monitoring in particular. We give a nonexhaustive overview of the complex institutional landscape and stress the leading role of the United Nations Framework Convention on Climate Change (UNFCCC) and four major multilateral financing institutions. Following this, we identify and briefly describe the two main carbon monitoring practices that are promoted by these institutions, namely remote sensing and national field inventories.

The ensuing two sections then present our main analytical steps that we took in order to identify dominant storylines connected to the key institutions and practices. Because distilling storylines is an interpretative and iterative process, we combined a deductive and an inductive step. In the first of these analytical sections, we compose an ex ante idea of what the key storylines might be, strongly drawing on earlier identifications of recurring types of overarching discourses in the discourse-analytical literatures on climate and environmental governance (Arts and Buizer 2009, Arts et al. 2010, Bäckstrand and Lövbrand 2006, Clapp and Dauvergne 2011, Dryzek 2013, Nielsen 2014). We translated these discourses for the context of REDD+ and assigned them to the two main groups of monitoring practices.

In the second analytical section, we apply these deductively gained storylines in a qualitative text analysis to different types of material, to explore which of these storylines are more or less influential across the REDD+ governance architecture when it comes to justifying and elaborating on specific monitoring practices. Because we assume that the dominance of certain storylines and the dominance of certain monitoring practices are mutually constituted, this second step combines an analysis of hierarchies within both dimensions: we identify recurring phrasings and references that prioritize and elaborate on, or sideline, specific interpretations, goals, stakeholders, and technologies, and that thereby reflect the dominance or neglect of specific monitoring practices as well as underlying storylines.

As our target material, we analyzed home pages, blogs, reports, and monitoring guidelines of the dominant multilateral institutions that we identify in the next section. In addition, to gather a more concrete picture of how monitoring practices are planned to unfold on the ground, we examined reports of selected countries to the major multilateral funding instruments. We chose eight countries, Argentina, Democratic Republic of Congo, Ethiopia, Laos, Mexico, Nigeria, Peru, and Viet Nam, based on the following criteria: membership of the country in at least two of the main multilateral financing institutions; geographical balance between Africa, Asia, and South America; availability of national documents; variation in GDP. We focused in particular on the so-called Readiness Preparation Proposals (R-PP) because they are most elaborate on the actual monitoring practices. We examined what they do or do not measure (carbon, biodiversity, or socioeconomic aspects), why they measure these aspects (climate change, sustainable forest management), how they measure, and who measures (satellites, experts, or local communities). 


\section{INSTITUTIONS IN COMPLEX REDD+ GOVERNANCE}

\section{The overarching REDD+ governance architecture}

The global REDD+ governance landscape exhibits a very diverse mix of intergovernmental institutions, bilateral arrangements and nongovernmental approaches (cf. Gupta et al. 2016). Adding to this, REDD+ pilot projects, which can become part of national REDD+ programs, are already up and running in different regions across the globe. Negotiations under the UNFCCC represent the decision-making hub in this architecture. After close to a decade of negotiations and several preliminary outcomes, UNFCCC parties agreed in 2013 on the Warsaw Framework on the implementation of $\mathrm{REDD}+$, including modalities for monitoring systems (UNFCCC Dec. 9-15/CP.19).

Outside the umbrella of the UNFCCC a series of institutions have come to address REDD+ and monitoring-related aspects thereof (cf. Corbera and Schroeder 2011, Thompson et al. 2011, Savaresi 2013). Given REDD+'s incentive-based nature, financing initiatives play a central role here. This includes established institutions like the Global Environment Facility and regional banks that administer their own funding mechanisms, such as the Amazon Fund or the Congo Basin Forest Fund. In addition, three major multilateral REDD+ financing initiatives have been brought on their way: the Forest Carbon Partnership Facility (FCPF) of the World Bank, launched at UNFCCC-COP 13 in 2007; the Forest Investment Programme (FIP), a multitrust fund in the World Bank's Strategic Climate Fund; and UNREDD (United Nations Collaborative Programme on Reducing Emissions from Deforestation and Forest Degradation). Furthermore, the UNFCCC's Green Climate Fund (GCF) has become a potential future financing option for national REDD+ programs, assuming that it will be endowed with the envisaged annual US $\$ 100$ billion from 2020 (GCF Decision B.08/08). Next to these multilateral bodies, a series of bilateral activities, by Norway, Germany, Japan, and the state of California in particular, contribute significantly to REDD+ financing.

Against the backdrop of this strong intergovernmental institutional involvement, private authority institutions perform largely agenda-setting, implementation, and evaluation functions. One institutional outcome of the engagement of NGOs and companies is the growing number of private REDD+ environmental and social safeguard certification schemes (Gupta et al. 2016, Duchelle et al. 2017). Voluntary carbon markets may also provide funding for REDD+ pilot projects. Currently however, only a fraction of the sums raised by such markets is associated with REDD+ projects. Other market-based approaches, and careful linking of domestic and subnational markets, might increase these figures in the next years. Ultimately, the future weight of private REDD+ financing is hard to predict and heavily depends on the implementation and success of REDD+ as a whole.

\section{Governing REDD+ monitoring}

Nearly each of the aforementioned institutions contains ideas or even regulations on specific aspects of REDD+, such as allocation criteria for funds, safeguards, and cobenefits, and monitoring of forest conservation and related carbon emission reductions. We concentrate our analysis on the monitoring, reporting, and verification (MRV) of REDD+ projects and their effects. Although this focus blanks out other interesting debates, it strongly overlaps with the question of safeguards and cobenefits. The choice of monitoring practices is directly linked to questions of sovereignty, the level of ambition of forest protection, and the involvement of particular stakeholders (cf. Schroeder and McDermott 2014, Collen et al. 2016).

The 2010 Cancún climate summit requested REDD+ countries to develop national strategies or action plans along with safeguard information systems (SIS). National forest monitoring systems were agreed, albeit voluntarily, to be linked to the safeguard information systems. A standoff between industrialized and developing countries prevented a concrete arrangement on MRV modalities. Developing countries opposed the idea of verification through third parties because this would infringe on their sovereignty (Sterk et al. 2012). It took until COP 19 in 2013, before a compromise on the selection of verification experts was reached as part of the Warsaw Framework (UNFCCC Dec. 9-15/CP.19). Notwithstanding this progress, the Framework leaves several crucial details to future negotiations and national circumstances. This includes financing modalities and a closer linking between monitoring and SIS, which still remains voluntary. Conservationist NGOs therefore keep demanding that "safeguards must also be subject to monitoring, reporting and verification ... and should be built into REDD+ programmes from the beginning" (WWF 2010:1).

UNFCCC negotiations may have the strongest ambition to frame the debate on a global level. But in light of their inconclusiveness, multilateral funding institutions currently dominate in shaping the actual practices of REDD+ on the ground, i.e., in their recipient countries. With nearly US\$2 billion as of October 2016, FCPF, FIP, and UN-REDD provide the bulk of pledged REDD+ financing, by far outspending the private sector and other public instruments. Although they base their practices on UNFCCC guidelines, they have considerable room for interpretation, e.g., when stepping in with operationally defined monitoring approaches including on safeguards. Adding to this, the GCF is expected to become an increasingly important funder for REDD+ and similar projects, and it will likely have similar leeway. Altogether then, intergovernmental institutions coming from the governance systems on climate change and development are most influential while, for instance, biodiversity-related institutions like the Convention on Biological Diversity do not play a major role here (cf. van Asselt 2014).

In our analysis, we therefore explore which monitoring approaches are recommended or required not only by the UNFCCC, but also by the GCF and the three currently key financing institutions in the REDD+ governance system. Table 1 summarizes the documents of the five institutions that we have taken into account. In addition, this question not only implies a look at multilateral institutions, but also at how countries plan to implement these requirements on the ground. We therefore included reports and latest progress sheets that the aforementioned countries submitted to the FCPF. Documentation for this funding institution is the most detailed and updated because it also contains emission reduction plans and regular country progress reports. 
Fig. 1. Overview of basic monitoring, reporting, and verification (MRV) system.

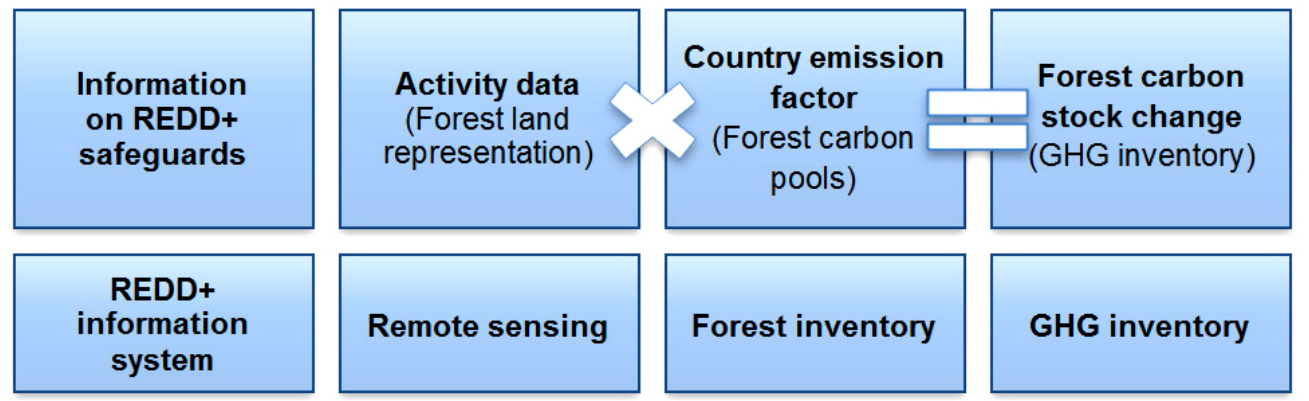

Table 1. Overview of empirical material.

\begin{tabular}{|c|c|}
\hline Funding Institution & Documents \\
\hline $\begin{array}{l}\text { United Nations Framework } \\
\text { Convention on Climate Change }\end{array}$ & $\begin{array}{l}\text { Decision booklet REDD+, Paris } \\
\text { Agreement, reports of the } \\
\text { Subsidiary Body for Scientific and } \\
\text { Technological Advice }\end{array}$ \\
\hline Forest Carbon Partnership Facility & $\begin{array}{l}\text { Monitoring guidelines, web site, } \\
\text { country reports (Readiness } \\
\text { Preparation Proposals, Emission } \\
\text { Reductions Program Idea Notes, } \\
\text { latest country progress sheets) }\end{array}$ \\
\hline Forest Investment Programme & Monitoring guidelines, web site \\
\hline $\begin{array}{l}\text { United Nations Collaborative } \\
\text { Programme on Reducing } \\
\text { Emissions from Deforestation and } \\
\text { Forest Degradation }\end{array}$ & $\begin{array}{l}\text { Monitoring guidelines, web site, } \\
\text { policy board meeting reports }\end{array}$ \\
\hline Green Climate Fund & $\begin{array}{l}\text { Monitoring guidelines, web site, } \\
\text { board meetings, GCF Readiness } \\
\text { Programme }\end{array}$ \\
\hline
\end{tabular}

\section{MONITORING PRACTICES IN COMPLEX REDD+ GOVERNANCE}

In the context of REDD+, carbon monitoring aims at estimating $\mathrm{CO}_{2}$ emissions due to deforestation and forest degradation. This requires establishing national MRV systems, which are based on the 2003 Good Practice Guidelines of the Intergovernmental Panel on Climate Change (Penman et al. 2003; UNFCCC Decision 2/CP.13). The aforementioned key funding institutions have in addition developed their own guidelines, albeit based on UNFCCC negotiations, to provide more details on how to operationalize REDD+. Their basic assumption is to focus on two key variables: (i) area of deforestation and degradation (activity data), and (ii) terrestrial carbon stock densities per unit area (emission factor). These shall be combined to create a national greenhouse gas (GHG) inventory to report anthropogenic forest-related GHG emissions to the UNFCCC Secretariat (cf. Decision 1/CP.16).

The monitoring practices described in the MRV guidelines can be largely categorized into two leading approaches: remote sensing and national forest inventories (NFI). These methods are used to assess activity data and emission factors with the goal to quantify the carbon "saved" by REDD+ activities, which ultimately is what such projects receive funding for. Together with the emerging safeguards information systems, remote sensing and national forest inventories form the core pillars of national MRV systems (see Fig. 1).

That said, several other monitoring methods and variations exist or are being discussed within the context of REDD+, such as, e.g., process modeling or community-based approaches. However, these are often in an infant stage with regard to implementation and evaluation plans and thus currently play a minor role in the documents covered by our study. This neglect or lack of detail regarding participatory practices, at least in the sense of widely recognized stand-alone monitoring methods, already insinuates a certain dominance pattern in REDD+ monitoring. Our analysis will further unpack the two major approaches, remote sensing and NFI, to analyze whether participatory and community-based elements at least play a role within these two leading approaches or whether other elements and, ultimately, storylines are prevailing.

Remote sensing consists of satellite-based optical and thermal images as well as radar and aerial photographs. The technique is able to provide, under optimal conditions, complete wall-towall information on forest cover changes with high temporal and spatial resolution on a global to regional scale, making it a suitable method for estimating forest activity data (DeFries et al. 2007). The advantages of remote sensing include its ability to provide spatially explicit information and frequent temporal coverage, the possibility of covering large and remote forest areas, and the potential to use historical data to provide a reference level for deforestation (cf. De Sy et al. 2012).

The main limitation of remote sensing is the inability to see beneath the canopy. Information such as soil carbon, biodiversity, and socioeconomic factors can only be vaguely linked to certain forest types and regions (e.g., Duro et al. 2007). Cloud coverage can also be a limiting factor, especially in the tropical region where REDD+ projects and programs are located. Technological and methodological advances in the use of remote sensing such as LiDAR provide promising ways to deal with some, but not all of these limitations (De Sy et al. 2012). In addition, the technical nature of remote sensing provides an obstacle to implementing it in a national monitoring scheme if 
Table 2. Overview of forest monitoring approaches.

\begin{tabular}{lll}
\hline \hline & Remote sensing & National Forest Inventories \\
\hline What & Wall to wall forest coverage & Sample based \\
& Regional to global scale & Local to regional scale \\
& Forest quantity & Forest quality \\
Why & Observes forest extent (activity data) & Measures carbon stocks and pools (emission factors) \\
& & Enables monitoring of social and environmental cobenefits \\
Who & Satellites, airplanes & Forest communities \\
& Providing near real-time trends in forest cover & Providing below canopy data \\
Advantage & Global coverage of data infrastructure already in place & Flexible, multiple monitoring objectives \\
& & Potentially engaging with local communities \\
& Limited information on noncarbon elements & Limited access to remote areas \\
Limitations & & Not always comparable on larger scales \\
& & Time-consuming
\end{tabular}

previous experience is lacking, and makes it less accessible for local communities and nongovernmental entities.

National forest inventories focus on field measurements of tree parameters. The methodology was developed during the 19th and 20th centuries to cater to a growing forestry industry sector, with the introduction of systematic sampling of forest properties such as age and tree volumes (Mohren et al. 2012). Since then forest inventories have been tailored to suit a diversity of further needs for information.

Two variations are commonly used, their choice depending on the purpose of the NFI: (1) inventories with the aim to create or update country-specific emission factors. Here NFI can make smaller interventions and focus them across various forest subcategories to measure different properties such as forest biomass and carbon content. The size and quality of the inventories corresponds directly to different tiers of national GHG accounting. (2) NFI can also be used to collect activity data, either through reported census data or large-scale field inventories.

The flexibility of NFIs helps with the inclusion of noncarbon components into REDD+ activities. Ground-level monitoring is essential in assessing aspects such as biodiversity and sustainable management (Visseren-Hamakers et al. 2012). Moreover, the inclusion of local communities in field inventories is feasible, often encouraged, and sometimes beneficial (Larrazábal et al. 2012). Many countries also want to utilize large-scale multipurpose NFIs for monitoring commercially related forest properties, providing additional financial incentives for their establishment.

Limitations of field inventories include that they are samplebased, which means that small-scale events such as logging or fires might be misrepresented. They are also time-consuming. Field personnel needs to be trained, and several forest characteristics need repeated measurements to be assessed, which may considerably delay the establishment of a baseline.

Finally, remote sensing and NFIs also differ in how they relate to the key problems targeted by REDD+, deforestation, and forest degradation. Remote sensing, on account of its listed benefits, is well suited for estimating the extent of deforestation. Forest degradation, on the other hand, is a less distinct process, with no single definition established (Morales-Barquero et al. 2014).
Because it involves quantification of changes in carbon over time, forest degradation is less easily identified through remote sensing and thus more dependent on extensive field inventories (Herold et al. 2011). This is especially true when the effects of indigenous peoples' land use are tracked by distant officials (Runk et al. 2010).

Table 2 summarizes the two currently major monitoring practices along with their technical strengths and shortcomings. Despite their differences, the mere fact that there are only two core monitoring approaches strongly contrasts with the considerable institutional complexity in REDD+ governance. This concentration on remote sensing and national forest inventories may as such not be surprising because there are only a limited number of techniques to assess forest carbon. The open question is how these two techniques are fleshed out and which aspects dominate, i.e., how actors choose to exploit their different potentials, and how these choices are justified. We have to look in greater detail at multilateral guidance documents and national implementation plans to gain more clarity on such choices, also about the extent to which REDD+ monitoring is planned to serve noncarbon objectives, and thereby to support the emerging safeguards information systems. Ultimately, this will give us insights into dominant mindsets or perspectives that inform these choices. This is where discursive storylines come in.

\section{STORYLINES IN REDD+ MONITORING PRACTICES I: DEDUCTIONS}

This and the next section comprise our two analytical steps and their findings. As described in our analytical framework, our first step is deductive: we derive storylines for each of the two monitoring practices from the discourse-analytical literature on forest governance and its application to REDD+ (Arts and Buizer 2009, Arts et al. 2010, Bäckstrand and Lövbrand 2006, Clapp and Dauvergne 2011, Dryzek 2013, Nielsen 2014). These storylines are not mutually exclusive and we will refer to how they overlap in our descriptions. They differ in how they emphasize or neglect certain uses and measurements of forests, social and environmental cobenefits, and societal levels. We find that, notwithstanding clear technical differences, the overlaps between some of these storylines reveal that remote sensing and NFI share discursive aspects, in particular a techno-managerial perspective. 


\section{Storylines in remote sensing}

A first storyline underlying remote sensing is techno-managerial. Remote sensing by definition incorporates technology-based analyses of a large quantity of data. This storyline draws attention to such calculative practices that turn stocks and flows of forest carbon into objects of governance (Lövbrand and Stripple 2011, Gupta et al. 2012). New mapping and accounting practices have opened up possibilities for the quantification and management of terrestrial carbon. This framing of global forests as carbon dioxide emissions offers to transform even the most lawless, impenetrable frontiers down to a highly "legible" unit, in this case a single chemical element (Boyd 2010). Hence, a key part of this storyline is framing deforestation as a particular type of problem, that of carbon management, amenable to a particular policy instrument, that of emissions reductions. It also promotes a high degree of faith in science and technology. It conveys the message to decision makers on REDD+ that forest carbon is measurable and consequently manageable (Lovell 2014). With continually improved data we may be able to gain a more and more fundamental understanding of the dynamics of deforestation and how to govern it. The storyline privileges scientific knowledge and expertise as the authoritative basis for managing forests.

The key rhetoric of a second storyline, commodification of forest carbon, is to convert a tropical forest into a homogenous unit that can be traded on an international market (Corbera and Brown 2010). From an economic perspective, this turns forests into a perfect commodity, potentially fully fungible without qualitative differentiation. This rationale synergizes well with remote sensing, which by necessity simplifies a complex picture, focusing on forest quantity and filtering out nuances. In the same vein, this storyline connects to the previous one because it relies heavily on the ability of scientists and foresters to determine the amount of carbon stored in forests and to measure and monitor deforestation. It ties closely to the concept of stratification used within remote sensing, dividing a forest into conceptually homogenous areas for observation. But in addition to this quantification, the storyline also emphasizes the role of markets and the importance of perfecting and expanding their functioning in order to find costeffective solutions to environmental problems (Humphreys 2008). As such, deforestation is seen as a problem of missing or false incentives, resulting from a missing valuation of forest ecosystem services in the economic system (Stephan et al. 2014). The storyline thus carries a win-win-win notion of achieving synergies between economic, ecological (biodiversity, water purification), and social aspects (poverty reduction, land tenure security) of REDD+ (Stern 2007).

The third storyline can be labeled global scale. Remote sensing allows (or encourages) analysts and stakeholders to look at tropical forests comprehensively (Gupta et al. 2012). It promotes local forest cover patterns to be considered as a unitary whole, capable of being understood and managed on a global level. The road to REDD+ began with the awareness that the forest sector accounted for more than $10 \%$ of global GHGs. This knowledge lies close to the raison d'être for engaging in REDD+ in the first place. By creating "facts on a planetary scale," remote sensing allows particular environmental problems to be understood and approached in ways (and at scales) that differ significantly from previous approaches (Jasanoff 2004). This fundamentally new perspective has profoundly altered our ability to visualize tropical deforestation and land cover change, providing the basis for a comprehensive, global mapping of forest carbon stocks (Boyd 2010).

\section{Storylines in national forest inventories}

One storyline we identify for NFI is similar to the first one we mentioned for remote sensing. Forest inventories may also cater to a techno-managerial rationale on REDD+. Indeed, most REDD+ projects combine remote sensing with some form of inventory measurement. Although NFI opens the possibility of measuring environmental and social cobenefits, its core aspect of assessing tree diameters or volumes still suggests the message that forest carbon is measurable and manageable. Similar to remote sensing, inventories may provide a prominent role to scientists and experts and suggest that respective technologies and data exist or will be available in due time.

Where NFI differs from remote sensing is in the noncarbon assessments it enables and in the views of the problem and solutions to REDD+ it accommodates. This can be conceptualized with the beyond carbon storyline. When forests are rendered legible through their carbon content only, other forest-related values and governance objectives, such as securing biodiversity or local livelihoods, may be obscured (Gupta et al. 2012). With NFI there is the possibility of a stronger emphasis on forest aspects that are less measurable by satellite. These can be grouped as social and ecological aspects that are seen as a prerequisite for a successful REDD+. The storyline stresses the social dimension as being crucial for REDD+ governance, for involving local stakeholders, enhancing social justice, and addressing some of the underlying social drivers of deforestation (cf. Hajek et al. 2011, Lyster 2011). It acknowledges a key role for local communities in designing and implementing carbon monitoring (Fry 2011). The ecological dimension highlights the importance of monitoring environmental cobenefits. The rhetoric is that if REDD+ projects and treaties do not include clauses on, for example, biodiversity, they will not cover the full picture of the devastation caused by deforestation.

A third storyline is a focus on a local view on REDD+ governance, which translates into an emphasis on the role of local stakeholders and participatory approaches as well as on the importance of local biodiversity. Given the absence of a systematic participatory monitoring approach in the reports we studied, this storyline is an important indicator for how much inclusive and communitybased elements have at least found their way into other practices and techniques like NFI. This local point of view may indeed be supported by the heterogeneous look on forests that NFIs provide (Mohren et al. 2012). This heterogeneous perspective questions the global and overarching view of forests that remote sensing projects. Such global perspectives, it is argued, ignore invisible and complex on-the-ground realities, which are embedded in local cultural practices and local knowledge (Litfin 1997). Table 3 summarizes our deductive linking of storylines for the two major monitoring approaches.

\section{DOMINANT STORYLINES IN REDD+ MONITORING PRACTICES II: EMPIRICAL ANALYSIS}

We now complement our deductive step with an inductive one To this end, we examine the existence and dominance of the previously introduced storylines through a qualitative text 
Table 3. Overview of REDD+ monitoring practices and their storylines.

\begin{tabular}{lll}
\hline \hline Monitoring practice & Storylines & Arguments \\
\hline Remote sensing & $\begin{array}{l}\text { Techno-managerial } \\
\text { Carbon commodification }\end{array}$ & $\begin{array}{l}\text { Calculative practices turning stocks and flows of forest carbon into objects of governance } \\
\text { Turning forests into comparable carbon stocks tradable on a market } \\
\text { Using market mechanisms to govern forests } \\
\text { (Promoting a win-win-win logic) }\end{array}$ \\
& Global view & $\begin{array}{l}\text { Enabling a global view on tropical forests } \\
\text { Converting tropical forests into a single unit }\end{array}$ \\
Cational Forest Inventory & $\begin{array}{l}\text { Calculative practices turning stocks and flows of forest carbon into objects of governance } \\
\text { Techno-managerial }\end{array}$ & $\begin{array}{l}\text { Focusing on cobenefits: inclusiveness, local participation, community forest monitoring, } \\
\text { biodiversity, ecosystems } \\
\text { Stressing the uniqueness of individual forest lands }\end{array}$ \\
\hline
\end{tabular}

analysis of selected documents of multilateral institutions and countries listed in Tables 1 and 4.

Following the theory-based assumption of a mutual constitution of practices and storylines, this second step of the analysis unfolds into two parts. We first examine to what extent the documents reflect a certain hierarchy among the two major REDD+ monitoring practices we identified. Here we find a clear dominance of remote sensing approaches in terms of their prioritization and the level of detail in the reports. Second, we analyze to what extent this hierarchy among practices coincides with the dominance of the storylines that we had associated with remote sensing in our deductive step. Indeed we identify such a prevalence of the techno-managerial, commodification, and global scale storylines. What is more, the techno-managerial prevalence also shapes the perspectives that the reports take on NFI while the other two NFI-related storylines are largely marginalized.

\section{Hierarchy among monitoring practices in complex REDD+ governance}

Across the sampled country reports we found a high level of detail in the remote sensing sections, regarding both design and implementation. This goes in particular for the Readiness Preparation Proposals (R-PPs) submitted to the FCPF. In their R-PPs, countries have to set out a clear plan, budget, and schedule for the REDD+ activities they seek to undertake. In our sample, all R-PPs keep very close to the Intergovernmental Panel on Climate Change guidelines and give very similar accounts of how they will operationalize them. This is not surprising: countries with a high monitoring capacity gap tend to stay closer to the description provided by manuals and give less elaborated descriptions of methodology (cf. Romijn et al. 2012).

Still, the country reports point to a heavy reliance on remote sensing and its clear prioritization over NFI. Sometimes this preference is explicitly stated, e.g., in the case of Democratic Republic of Congo (DRC 2010). Only one of the studied R-PPs suggests an alternative approach instead of simply using remote sensing-based estimates of activity data (Viet Nam 2011). Part of the reasoning behind this emphasis on remote sensing is that NFI (and safeguards information systems) take time to develop, while remote sensing images are readily available. Remote sensing also caters to quantifying the more approachable deforestation rather than the complex issue of forest degradation.

The use of NFIs, by contrast, is given a lower level of detail, on average, across the R-PPs. Several countries indicate little coherent experience on this practice: "As regards Nigeria no nation-wide scale or national forest inventory exists. The few inventories [that] were undertaken covered mostly the high forest zone (HFZ) and excluded some States in the arid region" (Nigeria 2014:86, cf. Nigeria 2013). That said, countries with previous forest inventories voiced a clear and continuous intention to incorporate these into the new monitoring system (e.g., Lao PDR 2010, 2015, 2017, Viet Nam 2011, 2014, 2017). Thus, variation is considerable across the R-PPs on NFIs, especially on how to operationalize NFIs and on how to monitor social and environmental safeguards. This variation, along with more detailed references and plans for NFI, also continues in the Emission Reductions Program Idea Notes (ER-PINs), a second set of shorter reports that most countries submitted to the FCPF.

We further found for our sample that both the level of implementation of field inventories and previous experience with them are positively correlated with country GDP. This may be explained with the potentially more developed forest industries in the respective countries and the subsequent demand of forestryrelated information. The collection of such information in the NFIs is explicitly stated in several R-PPs and ER-PINs of countries like Ethiopia (2011a, b, 2015) and Peru (2013, 2014).

These less developed plans for implementing and operationalizing NFIs go hand in hand with a lack of prioritization, detail, and coherence on cobenefits across governance levels. Although all country reports mention cobenefits extensively, frame them as quintessential to REDD+, and stress their intent to monitor them, most R-PPs provide little detail on how they plan to do so, and this continues in the ER-PINs where one could have expected more detailed plans on this matter (c.f. Peru 2013, 2014). This clearly points at little or no intention to link monitoring efforts more strongly to safeguard information systems. Similarly, while they all are in line with UNFCCC decisions, there are discrepancies amongst multilateral funding organizations. The GCF (2014) allows for goals that go beyond REDD+ and move toward a comprehensive approach of sustainable forest management. The Global Environment Facility (GEF 2010, 2014) stresses more environmental cobenefits, while UN-REDD $(2012,2013 a)$ has a slightly more rights-based approach than FCPF.

Only a few countries, those with previous experience with NFI or community forest management, provide lists of suggested monitoring indicators for cobenefits, while most R-PPs at best propose that such a list should be developed. "Capacity to 
Table 4. Overview of Readiness Preparation Proposals (R-PP) country report findings.

\begin{tabular}{|c|c|c|}
\hline Reporting Country & Carbon monitoring practice & Cobenefits \\
\hline Argentina & $\begin{array}{l}\text { High level of detail on remote sensing; } \\
\text { low level of detail on national forest inventories } \\
(\mathrm{NFI})\end{array}$ & $\begin{array}{l}\text { Low level of detail on social cobenefits; } \\
\text { moderate level of detail on environmental cobenefits, } \\
\text { especially participatory biodiversity-monitoring. }\end{array}$ \\
\hline Democratic Republic of Congo & $\begin{array}{l}\text { High level of detail and focus on remote sensing; } \\
\text { low level of detail on NFI. }\end{array}$ & $\begin{array}{l}\text { Clear intent, but low level of detail on both social and } \\
\text { environmental cobenefits (measurement and } \\
\text { operationalization). }\end{array}$ \\
\hline Ethiopia & $\begin{array}{l}\text { High level of detail on remote sensing; } \\
\text { moderate detail on NFI. }\end{array}$ & $\begin{array}{l}\text { Moderate to high level of detail on environmental and } \\
\text { social cobenefits (measurement and } \\
\text { operationalization), with concrete examples of } \\
\text { biodiversity indicators and plans for stakeholder } \\
\text { engagement and community forest management. }\end{array}$ \\
\hline Lao People's Democratic Republic & $\begin{array}{l}\text { Moderate detail on remote sensing; } \\
\text { moderate detail on NFI; multiple monitoring } \\
\text { initiatives. }\end{array}$ & $\begin{array}{l}\text { Moderate level of detail on measurement of } \\
\text { environmental and social co-benefits; } \\
\text { Low level of detail on operationalization. }\end{array}$ \\
\hline Mexico & $\begin{array}{l}\text { High level of detail on remote sensing; } \\
\text { large permanent NFI. }\end{array}$ & $\begin{array}{l}\text { Low level of detail on both environmental and social } \\
\text { cobenefits (measurement and operationalization). }\end{array}$ \\
\hline Nigeria & $\begin{array}{l}\text { Low level of detail on remote sensing; } \\
\text { high level of detail on NFI. }\end{array}$ & $\begin{array}{l}\text { Low level of detail on both environmental and social } \\
\text { cobenefits (measurement and operationalization), with } \\
\text { some efforts at stakeholder engagement. }\end{array}$ \\
\hline Paraguay & $\begin{array}{l}\text { Low level of detail on remote sensing; } \\
\text { high level of detail on NFI. }\end{array}$ & $\begin{array}{l}\text { Moderate level of detail on environmental and social } \\
\text { cobenefits (measurement and operationalization), with } \\
\text { some efforts of stakeholder engagement; } \\
\text { Moderate level of detail on operationalization through } \\
\text { an information system. }\end{array}$ \\
\hline Peru & $\begin{array}{l}\text { High level of detail on remote sensing; } \\
\text { low level of detail on NFI. }\end{array}$ & $\begin{array}{l}\text { Moderate level of detail on measurement of social and } \\
\text { environmental cobenefits, with a list of environmental } \\
\text { indicators and concrete efforts of stakeholder } \\
\text { engagement; } \\
\text { low level of detail on operationalization. }\end{array}$ \\
\hline Viet Nam & $\begin{array}{l}\text { Low level of detail on remote sensing; } \\
\text { large owner-based NFI. }\end{array}$ & $\begin{array}{l}\text { High level of detail on social cobenefits, with reference } \\
\text { to previous experience; } \\
\text { low level of detail on environmental cobenefits. }\end{array}$ \\
\hline
\end{tabular}

undertake such monitoring [of cobenefits] is very limited at present and so progress will depend on donor support for funding and for building up capacity" (Lao PDR 2010:84). This sparse consideration of community-based management and monitoring in the reports coincides with the realities that several studies found on the ground for these and other countries: the lack of a more nuanced policy approach that facilitates bottom-up institutional development for a stronger community involvement (Danielsen et al. 2013, Collen et al. 2016).

\section{Hierarchy among monitoring storylines in complex REDD+ governance}

Across the guidelines of all major funding organizations and the country reports we find a clear prevalence of the technomanagerial storyline, in particular the argument that an accurate and detailed MRV is the foundation for implementing REDD+. "A robust and transparent national forest monitoring system can contribute to strengthen forest governance and to further consider counter measures to deforestation and forest degradation" (FCPF 2013:17). Furthermore, forests are often spoken of in terms of carbon pools, sinks, removals, tons of $\mathrm{CO}_{2}$ or forest area, terms that frame them as a governable unit. All country reports convey a high degree of confidence that the appropriate monitoring of forest carbon changes is achievable through different indicators and techniques (cf. FCPF 2016), for instance, "With regard to the reference scenario and the MRV system, the DRC will develop compatible systems with the most demanding carbon reporting criteria" (DRC 2010:12, cf. DRC 2013).

The carbon commodification storyline is identifiable in most country reports where REDD+ is framed as a significant new source of finance for effective implementation of forest management strategies (cf. Lao PDR 2010, 2015). The win-winwin logic is used as a key legitimization of REDD+ across all institutions and most reports under scrutiny, for example, "This will ensure that the REDD+ implementation process generates a balance of social, economic, and environmental benefits in forest environments and rural populations that occupy the territory in question" (Paraguay 2015:134). In a more encompassing reading of this logic, multilateral institutions see the REDD+ process as an engine to design and implement a low carbon economy (cf. UN-REDD 2013b, GCF 2014). REDD+ is further framed in some country reports as an approach that promotes public and private investment in forest carbon trade, and that is able to secure (financial) incentives for sustainable forest management (cf. Lao PDR 2010, 2015). The financing instruments often aim for countries or REDD+ projects to reach a level where they become able to secure their own funding (cf. UN-REDD 2013a).

The global scale storyline is not as pronounced as technomanagerial and commodification aspects in the documents we studied, which can be partly explained with the majority of country reports in our sample and their necessary focus on 
translating international guidelines into domestic and subdomestic implementation. This notwithstanding, the aforementioned reliance on universal, i.e., not country- or context-specific, indicators and techniques in multilateral guidance documents (FCPF 2013, 2016) strongly promotes the idea of a global mapping of carbon stocks.

The beyond carbon storyline is articulated in different ways, emphasizing the importance of paying special attention to biodiversity, ecosystem services, transparent and effective governance, participation, inclusion of stakeholders, and indigenous people's rights (cf. UN-REDD 2012). That said, when it comes to securing social safeguards, e.g., empowering and including local stakeholders in the decision-making and monitoring practices, this is often framed in terms of reducing risks by increasing effectiveness, climate resilience, and investment security. For instance, "Nigeria is committed to ensuring that forests under a REDD+ regime deliver benefits beyond carbon and avoid potential risks to the environment and social wellbeing" (Nigeria 2014:8). And even more explicitly, "Participatory monitoring will strengthen their [local communities'] understanding and commitment while providing a degree of comfort to investors that REDD+ is sustainable" (Viet Nam 2011:10). In other words, all country reports highlight the importance of safeguards, but clearly in the role of cobenefits to achieving emissions reductions. While not ceasing to pay lip service to safeguards, the reports do not break away from the carbon commodification storyline and its win-win-win rhetoric. This prioritization of commodification over safeguards is specifically evident in the reports' lack of clear information on plans to monitor and operationalize safeguards.

Participatory elements, thus, are hardly elaborated, let alone combined into full-fledged or stand-alone sets of monitoring methods in their own right. The R-PP for DRC, for instance, suffices with the general ambition that "the MRV system will be based on a participatory analysis of the dimensions and will be implemented in a participatory manner (informed by the REDD stakeholder consultation strategy)" (DRC 2010:84), without spelling out this vision into specific mechanisms and stages in the remainder of the document. Other country reports at least name such mechanisms, e.g., workshops, consultancy, communication among stakeholders, but do so only sporadically and without merging such ideas into systematic approaches or specific chapters (cf. Argentina 2010, Lao PDR 2010, Mexico 2010, Viet Nam 2011, Nigeria 2013, Paraguay 2015). The two only exceptions to this lack of precision in our sample are Ethiopia $(2011 a, b)$ and Peru $(2013,2014)$ who in their reports frequently refer to stakeholder inclusion at different stages from decision making to implementation and evaluation.

Such mostly placative and abstract references to participatory and community-based aspects also affect the relevance of the local view storyline, which is reflected in requirements to adjust or account for domestic and local circumstances, national strategies, and national policies (cf. Decision 1/CP.16 Appendix 1). The UNFCCC guidelines on how to include safeguards make frequent use of phrases like "in accordance with national circumstances." This rhetoric is echoed in the country reports that often argue for a need to break REDD+ into national and subnational levels or into different forest or deforestation categories. Indeed, the multilateral funding institutions can only provide guidance and support, but it is individual countries that, in their implementation plans, need to adjust the hundreds of monitoring indicators to local circumstances. Across its R-PP versions and its ER-PIN, the Argentinian government, for instance, stressed the necessity to develop eco-regional strategies to address all issues of REDD+ for the specific conditions of each ecoregion (Argentina 2010, 2014, 2015). This emphasis notwithstanding, Argentina's latest progress report does not refer to the matter (Argentina 2017). As mentioned, other countries at least relate modestly to local stakeholders and regions in their communications, e.g., DRC (2017), Paraguay (2017), while only Ethiopia (2015) and Peru (2015) provide detailed plans for stakeholder engagement. Especially the sections on NFI in reports of these countries often emphasize local knowledge and promote community forest monitoring. "In the case of native communities, their participation in forest monitoring is essential due to their understanding of the land and traditional knowledge, thus enabling efficient and effective monitoring" (Peru 2013:125).

\section{CRITICAL DISCUSSION OF RESULTS}

Table 4 roughly summarizes our analysis of the country reports. Our study indicates that there is no consistent balance between remote sensing and forest inventory. Remote sensing is clearly dominant across the complex REDD+ governance landscape: horizontally, across core multilateral institutions, and vertically, across selected domestic implementation plans. This dominance is not only reflected in the much more detailed plans for its operationalization, but also in terms of the storylines that are coconstituted with remote sensing.

How can we interpret these results? Although the prioritization of remote sensing is often made due to technical considerations like those listed in Table 2, this choice also perpetuates a certain understanding of forests and REDD+. The hegemony of remote sensing as a monitoring practice caters particularly to technomanagerial and carbon commodification views on REDD+, but also implicitly to a global-universal understanding. In spite of a growing rhetoric on triple wins and the importance of cobenefits, this dominance signals a largely carbon-centric perspective that treats a forest as a single homogeneous unity, simplifying tropical forest ecosystems into calculable objects of carbon on a global scale (Lovell 2014). This rationale ultimately implies decoupling forest carbon from its ecological context and inserting it into new, increasingly global carbon value chains (Boyd 2010).

Viewing the technological advances of remote sensing as steps toward a more fundamental understanding of deforestation misses the fact that this is a problem that has no single essence or identity waiting to be discovered. The risk is that such a perspective becomes reinforced and normalized by the interplay between institutions' practices and discourses. The lack of detail on safeguards, i.e., the implicitness or ambiguity on monitoring cobenefits, may increasingly legitimize the carbon commodification and techno-managerial storylines, rather than serving as a check on them. The over-reliance on experts, including the ones writing the country reports, and advanced technologies sets obstacles to a more widespread understanding and support or REDD+.

Our results also show that a stronger reliance on NFIs would not necessarily mark a change toward a more diversified and safeguard-protective view on deforestation and forest 
degradation. On balance, current NFI development further promotes a techno-managerial orientation and benefits the local forestry industries rather than other stakeholders. For example, Mexico's R-PP and ER-PIN do not offer a high level of detail on cobenefits monitoring, in spite of featuring the most developed NFI plans of all sampled country reports (Mexico 2010, 2013). And the country's latest progress report to the FCPF contained no plans for an information system on multiple benefits (Mexico 2016, and equally Nigeria 2017).

If remote sensing and NFIs were not dominated by a technomanagerial approach this would arguably facilitate a more comprehensive understanding of forests as complex socialecological systems and enable a stronger focus on safeguards (McDermott et al. 2012). The current dominant storylines and monitoring approaches largely overlook the socioeconomic, culture, gender, and biological aspects in forests, which are less quantifiable under current techniques, but crucial for the ecosystem services and functions of forests (Nielsen 2014).

To achieve a more comprehensive view would, thus, require a higher importance of beyond carbon and local view storylines. This, in turn necessitates a stronger acknowledgement of other types of knowledge and values for how to assess the viability of forests (Gupta et al. 2012). Such a stronger importance of alternative storylines would arguably entail the inclusion of more participatory and safeguard-protective elements into NFIs and, where possible, remote sensing. But ultimately it could imply a stronger emphasis on entire alternative monitoring practices, such as participatory and particularly community-based forms of forest monitoring. The option of such systematic participatory monitoring mechanisms or systems that are at eye-level with NFIs and remote sensing has been mostly neglected, not only in the early days of REDD+ (Fry 2011) but also in most of the more recent country reports we analyzed.

\section{CONCLUDING REMARKS}

In this article we developed a novel framework to analyze complex governance architectures, building on argumentative discourse analysis and the core concept of discursive storylines. We followed the starting assumption that discourses, practices, and institutional complexes are mutually constituted. Based on this assumption we argued that, beyond the intricate and messy surface of institutional fragmentation or complexity, there may be joint patterns of dominance that run across institutions and scales.

We substantialized and explored this framework for the case of REDD+ monitoring by matching specific discursive storylines with the two key monitoring practices and dominant financial institutions. We could illustrate the prevalence of remote sensing that goes hand in hand with the dominance of technocratic, market-liberal, and global perspectives. Drawing these connections showed that monitoring practices are not neutral tools, but enable and promote certain discourses that in turn shape certain views within REDD+, with certain types of information being prioritized over others.

This finding has normative implications that go beyond REDD+ and affect the wider governance architecture on land use. Efforts to account and report land use-related GHGs at the UNFCCC are faced with a patchwork of different guidelines and mechanisms. For example, the Clean Development Mechanism focuses only on afforestation and reforestation within the forest sector, while REDD+ accounting guidelines include a broader range of forest activities. Yet, unlike guidelines for Land Use, Land-Use Change and Forestry, REDD+ guidelines do not cover carbon mitigation from certain land-use activities outside of forests. Parties to the UNFCCC have expressed a desire to harmonize and simplify these different methodologies, but so far with little success (Estrada et al. 2014, Iversen et al. 2014). The discussion over what to include or not to include will become even more relevant in years to come, as will the need to make sense of an ever more complex governance architecture.

We could only provide explorative insights here, which implies clear limitations for any generalizability, e.g., when it comes to the neglect of participatory REDD+ monitoring approaches. Empirically, a comprehensive analysis would need to rely on a larger set of organizations, governance instruments, and countries, a longer observation period, and additional methods like interviews and field studies. And ultimately, the connection of institutions, practices, and discourses could be examined for a whole series of other environmental and nonenvironmental policy fields. In theoretical terms, our approach stayed pragmatic and employed some selected discourse-analytical concepts to the study of institutional complexity. A more encompassing approach could systematically include the hierarchy among actors in relation to discursive and institutional hierarchies, e.g., by building on Hajer's more recent work and widening the analytical scope toward network governance and changing dynamics of authority in a complex governance system like that of REDD+ (Hajer 2009).

We hope that our approach can inspire such research endeavors: academically, for further theoretical development to help identify opportunities and shortcomings of institutional complexity; and practically, to provide informed recommendations to practitioners and stakeholders on how to understand and navigate complex environmental governance systems.

Responses to this article can be read online at: http://www.ecologyandsociety.org/issues/responses. php/10632

\section{Acknowledgments:}

We are indebted to the strategic research programme BECC (Biodiversity and Ecosystem Services in a Changing Climate) at Lund University and the University of Gothenburg for its financial and logistical support. Special thanks to our colleagues Lars Eklundh, Anna Nordén, and Fredrik Lagergren from the BECC action group on forestry monitoring, and to Ingrid VisserenHamakers for her very helpful comments.

\section{LITERATURE CITED}

Abbott, K. W., J. F. Green, and R. O. Keohane. 2016. Organizational ecology and institutional change in global governance. International Organization 70:247-277. http://dx.doi. org/10.1017/S0020818315000338 
Argentina. 2010. Readiness Preparation Proposal ( R-PP). Forest Carbon Partnership Facility. [online] URL: https://www. forestcarbonpartnership.org/sites/forestcarbonpartnership.org/files/ Documents/PDF/Jun2010/Argentina_R-PP_June_2010_0.pdf

Argentina. 2014. Revised Readiness Preparation Proposal ( $R$ $P P)$. Forest Carbon Partnership Facility. [online] URL: https:// www.forestcarbonpartnership.org/sites/fcp/files/Revised $\% 20 \operatorname{Argentinian} \%$ 20R-PP-January $\% 202014 \% 20$ version.pdf

Argentina. 2015. Emission Reductions Program Idea note (ER$P I N)$. Forest Carbon Partnership Facility. [online] URL: https:// www.forestcarbonpartnership.org/sites/fcp/files/2015/September/ ER-PIN $\% 20$ Argentina $\% 20$ final $\% 2021$ set $\% 202015$.pdf

Argentina. 2017. Country Progress Sheet. Forest Carbon Partnership Facility. [online] URL: https://www.forestcarbonpartnership. org/sites/fcp/files/2017/July/FCPF $\% 20$ Country $\% 20$ Progress $\%$

20Reporting $\% 20$ Argentina.pdf

Arts, B., J. Behagel, S. van Bommel, J. de Koning, and E. Turnhout, editors. 2010. Forest and nature governance: a practice based approach. Springer, Heidelberg, Germany.

Arts, B., and M. Buizer. 2009. Forests, discourses, institutions: a discursive-institutional analysis of global forest governance. Forest Policy and Economics 11:340-347. http://dx.doi. org/10.1016/j.forpol.2008.10.004

Bäckstrand, K., and E. Lövbrand. 2006. Planting trees to mitigate climate change: contested discourses of ecological modernization, green governmentality and civic environmentalism. Global Environmental Politics 6:50-75. http://dx.doi.org/10.1162/ glep.2006.6.1.50

Bernstein, S. 2002. Liberal environmentalism and global environmental governance. Global Environmental Politics 2:1-16. http://dx.doi.org/10.1162/152638002320310509

Biermann, F., P. Pattberg, H. van Asselt, and F. Zelli. 2009. The fragmentation of global governance architectures: a framework for analysis. Global Environmental Politics 9:14-40. http://dx.doi. org/10.1162/glep.2009.9.4.14

Boyd, W. 2010. Ways of seeing in environmental law: how deforestation became an object of climate governance. Ecology Law Quarterly 37:843-916.

Clapp, J., and P. Dauvergne. 2011. Paths to a green world. The political economy of the global environment. Second edition. MIT Press, Cambridge, Massachusetts, USA. http://dx.doi.org/10.7551/ mitpress/5265.001.0001

Collen, W., T. Krause, L. Mundaca, and K. A. Nicholas. 2016. Building local institutions for national conservation programs: lessons for developing Reducing Emissions from Deforestation and Forest Degradation (REDD+) programs. Ecology and Society 21(2):4. http://dx.doi.org/10.5751/ES-08156-210204

Corbera, E., and K. Brown. 2010. Offsetting benefits? Analyzing access to forest carbon. Environment and Planning $A$ 42:1739-1761. http://dx.doi.org/10.1068/a42437

Corbera, E., and H. Schroeder. 2011. Governing and implementing REDD+. Environmental Science and Policy 14:89-99. http://dx.doi.org/10.1016/j.envsci.2010.11.002
Danielsen, F., T. Adrian, S. Brofeldt, M. van Noordwijk, M. K. Poulsen, S. Rahayu, E. Rutishauser, I. Theilade, A. Widayati, N. The An, T. Nguyen Bang, A. Budiman, M. Enghoff, A. E. Jensen, Y. Kurniawan, Q. Li, Z. Mingxu, D. Schmidt-Vogt, S. Prixa, V. Thoumtone, Z. Warta, and N. Burgess. 2013. Community monitoring for REDD+: international promises and field realities. Ecology and Society 18(3):41. http://dx.doi.org/10.5751/ ES-05464-180341

De Sy, V., M. Herold, F. Achard, G. P. Asner, A. Held, J. Kellndorfer, and J. Verbesselt. 2012. Synergies of multiple remote sensing data sources for REDD+ monitoring. Current Opinion in Environmental Sustainability 4:696-706. http://dx.doi.org/10.1016/ j.cosust.2012.09.013

DeFries, R., F. Achard, S. Brown, M. Herold, D. Murdiyarso, B. Schlamadinger, and C. de Souza Jr. 2007. Earth observations for estimating greenhouse gas emissions from deforestation in developing countries. Environmental Science and Policy 10:385-394. http://dx.doi.org/10.1016/j.envsci.2007.01.010

Democratic Republic of Congo (DRC). 2010. Readiness Preparation Proposal (R-PP). Forest Carbon Partnership Facility. [online] URL: https://www.forestcarbonpartnership.org/ sites/forestcarbonpartnership.org/files/Documents/PDF/Jul2010/ R-PP V3.1 English July2010.pdf

Democratic Republic of Congo (DRC). 2013. Emission Reductions Program Idea note (ER-PIN). Forest Carbon Partnership Facility. [online] URL: https://www.forestcarbonpartnership. org/sites/fcp/files/2013/june2013/ER-PIN DRC 17May2013 0.pdf

Democratic Republic of Congo (DRC). 2017. Country Progress Sheet. Forest Carbon Partnership Facility. [online] URL: https:// www.forestcarbonpartnership.org/sites/fcp/files/2016/Sep/DRC\% 20FCPF $\% 20$ Country $\% 20$ Progress $\% 20$ Report $\% 20$ FY $\% 2016$.pdf

Dryzek, J. S. 2013. The politics of the Earth: environmental discourses. Third edition. Oxford University Press, Oxford, UK.

Duchelle, A. E., C. de Sassi, P. Jagger, M. Cromberg, A. M. Larson, W. D. Sunderlin, S. S. Atmadja, I. A. P. Resosudarmo, and C. D. Pratama. 2017. Balancing carrots and sticks in REDD+: implications for social safeguards. Ecology and Society 22(3):2. http://dx.doi.org/10.5751/ES-09334-220302

Duro, D. C., N. C. Coops, M. A. Wulder, and T. Han. 2007. Development of a large area biodiversity monitoring system driven by remote sensing. Progress in Physical Geography 31:235-260. http://dx.doi.org/10.1177/0309133307079054

Ekstrom, J. A., and O. R. Young. 2009. Evaluating functional fit between a set of institutions and an ecosystem. Ecology and Society 14(2):16. http://dx.doi.org/10.5751/ES-02930-140216

Estrada, M., D. Lee, B. Murray, R. O'Sullivan, J. Penman, and C. Streck. 2014. Land use in a future climate agreement. Prepared with support from cooperative agreement \# S-LMAQM-13CA-1128 with U.S. Department of State. Meridian Institute, Dillon, Colorado, USA. [online] URL: http://merid.org/landuse-in-ADP/

Ethiopia. 2011a. Readiness Preparation Proposal ( R-PP). Forest Carbon Partnership Facility. [online] URL: https://www. forestcarbonpartnership.org/sites/fcp/files/Documents/PDF/Jan2012/ R-PP $\% 20$ Ethiopia-final $\% 20 \mathrm{May} \% 2025-2011 . p d f$ 
Ethiopia. 2011b. Revised R-PP. Forest Carbon Partnership Facility. [online] URL: http://www.forestcarbonpartnership.org/ sites/forestcarbonpartnership.org/files/Documents/PDF/Jan2012/ R-PP $\% 20$ Ethiopia-final $\% 20 \mathrm{May} \% 2025-2011$.pdf

Ethiopia. 2015. Country Progress Sheet. Forest Carbon Partnership Facility. [online] URL: https://www.forestcarbonpartnership. org/sites/fcp/files/2015/April/Ethiopia Semi-Annual\%

\section{Report FCPF 31515 Final.pdf}

Fairclough, N. 1992. Discourse and social change. Polity, Cambridge, UK.

Fisher, F. 2003. Framing public policy: discursive politics and deliberative practices. Oxford University Press, Oxford, UK. http://dx.doi.org/10.1093/019924264X.001.0001

Folke, C., L. Pritchard, F. Berkes, J. Colding, and U. Svedin. 2007. The problem of fit between ecosystems and institutions: ten years later. Ecology and Society 12(1):30. http://dx.doi.org/10.5751/ ES-02064-120130

Forest Carbon Partnership Facility (FCPF). 2013. A guide to the FCPF readiness assessment framework. [online] URL: https:// www.forestcarbonpartnership.org/sites/fcp/files/2013/june2013/FCPF $\%$ 20R-Package $\% 20$ User $\% 20$ Guide $\% 20$ ENG $\% 206-18-13 \% 20$ web.pdf

Forest Carbon Partnership Facility (FCPF). 2016. Revised methodological framework for the carbon fund of the FCPF. [online] URL: https:/www.forestcarbonpartnership.org/sites/ fcp/files/2016/June/FCPF\%20CF14_Resolution_CFM_14_20164 Revised $\% 20 \mathrm{MF}$ FINAL.pdf

Fry, B. P. 2011. Community forest monitoring in REDD+: The 'M' in MRV? Environmental Science and Policy 14:181-187. http:// dx.doi.org/10.1016/j.envsci.2010.12.004

Gehring, T., and B. Faude. 2013. The dynamics of regime complexes: microfoundations and systemic effects. Global Governance 19:119-130. http://dx.doi.org/10.1163/19426720-01901010

Global Environment Facility (GEF). 2010. The GEF incentive mechanism for forests: a new REDD+ multilateral finance program. GEF, Washington, D.C., USA. [online] URL: https:// www.thegef.org/sites/default/files/publications/REDDEnglish 2. pdf

Global Environment Facility (GEF). 2014. GEF-6 sustainable forest management strategy: strengthened support for forests. GEF, Washington, D.C., USA. [online] URL: https://www.thegef.org/ sites/default/files/publications/GEF_Forests-20142_2.pdf

Green, J. 2014. Rethinking private authority: agents and entrepreneurs in global environmental governance. Princeton University Press, Princeton, New Jersey, USA.

Green Climate Fund (GCF). 2014. Initial logic model and performance measurement framework for REDD+ results-based payments. Doc. No. GCF/B.08/08/Rev.01. GCF, Incheon, South Korea. [online] URL: https://www.greenclimate.fund/ documents/20182/24946/GCF B.08 08 Rev.01 -

Initial_Logic_Model_and_Performance_Measurement_Framework_for_REDD Results-based_Payments.pdf/af196e83-86cd-45b3b220-463e12827920
Gupta A., E. Lövbrand, E. Turnhout, and M. J. Vijge. 2012. In pursuit of carbon accountability: the politics of REDD+ measuring, reporting and verification systems. Current Opinion in Environmental Sustainability 4:726-731. http://dx.doi. org/10.1016/j.cosust.2012.10.004

Gupta, A., T. Pistorius, and M. J. Vijge. 2016. Managing fragmentation in global environmental governance: the REDD+ Partnership as bridge organization. International Environmental Agreements 16:355-374. http://dx.doi.org/10.1007/s10784-015-9274-9

Hajek, F., M. J. Ventresca, J. Scriven, and A. Castro. 2011. Regime-building for REDD+: evidence from a cluster of local initiatives in south-eastern Peru. Environmental Science and Policy 14:201-215. http://dx.doi.org/10.1016/j.envsci.2010.12.007

Hajer, M. 1995. The politics of environmental discourse: ecological modernization and the policy process. Oxford University Press, Oxford, UK.

Hajer, M. 2006. Doing discourse analysis: coalitions, practices, meaning. Pages 65-74 in M. van den Brink and T. Metze, editors. Words matter in policy and planning: discourse theory and method in the social sciences. Koninklijk Nederlands Aardrijkskundig Genootschap, Utrecht, Netherlands.

Hajer, M. 2009. Authoritative governance: policy making in the age of mediatization. Oxford University Press, Oxford, UK. http://dx. doi.org/10.1093/acprof:oso/9780199281671.001.0001

Hajer, M., and M. Versteeg. 2005. A decade of discourse analysis of environmental politics: achievements, challenges, perspectives. Journal of Environmental Policy and Planning. 7:175-184. http:// dx.doi.org/10.1080/15239080500339646

Herold, M., R. M. Román-Cuesta, D. Mollicone, Y. Hirata, P. Van Laake, G. P. Asner, C. Souza, M. Skutsch, V. Avitabile, and K. MacDicken. 2011. Options for monitoring and estimating historical carbon emissions from forest degradation in the context of REDD+. Carbon Balance and Management 6:1-7. http://dx. doi.org/10.1186/1750-0680-6-13

Humphreys, D. 2008. The politics of 'avoided deforestation': historical context and contemporary issues. International Forestry Review 10:433-442. http://dx.doi.org/10.1505/ifor.10.3.433

Iversen, P., D. Lee, and M. Rocha. 2014. Understanding land use in the UNFCCC. Climate and Land Use Alliance, San Francisco, California, USA. [online] URL: http://www.climateandlandusealliance. org/wp-content/uploads/2015/08/Understanding_Land_Use_in_the UNFCCC.pdf

Jasanoff, S. 2004. Earthly politics: local and global environmental governance. MIT Press, Cambridge, Massachusetts, USA.

Kaplan, T. J. 1986. The narrative structure of political analysis. Journal of Policy Analysis and Management 5:761-778. http://dx. doi.org/10.2307/3324882

Lao People's Democratic Republic (Lao PDR). 2010. Readiness Preparation Proposal (R-PP). Forest Carbon Partnership Facility. [online] URL: https://www.forestcarbonpartnership.org/ sites/forestcarbonpartnership.org/files/Documents/PDF/Sep2011/ Lao $\% 20$ R-PP $\% 20$ Final $\% 20$ draft $\% 20$ revised $\% 2021 \% 20$ DEC $\% 202010$ CLEAN.pdf 
Lao People's Democratic Republic (Lao PDR). 2015. Emission Reductions Program Idea note (ER-PIN). Forest Carbon Partnership Facility. [online] URL: https://www.forestcarbonpartnership. org/sites/fcp/files/2015/September/La $\% 20$ PDR $\% 20$ FCPF $\% 20$ Carbon $\%$ 20Fund $\% 20$ ER-PIN.pdf

Lao People's Democratic Republic (Lao PDR). 2017. Country Progress Sheet. Forest Carbon Partnership Facility. [online] URL: https://www.forestcarbonpartnership.org/sites/fcp/files/2017/July/ FCPF $\% 20$ Country $\% 20$ Progress $\% 20$ Report $\% 20$ Lao $\% 20$ PDR July $\%$ 202017.pdf

Larrazábal, A., M. K. McCall, T. H. Mwampamba, and M. Skutsch. 2012. The role of community carbon monitoring for REDD+: a review of experiences. Current Opinion in Environmental Sustainability 4:707-716. http://dx.doi.org/10.1016/ j.cosust.2012.10.008

Litfin, K. T. 1997. The gendered eye in the sky: a feminist perspective on earth observation satellites. Frontiers: A Journal of Women Studies 18:26-47. http://dx.doi.org/10.2307/3346964

Lovell, H. 2014. Measuring forest carbon. Pages 175-196 in J. Stripple and H. Bulkeley, editors. Governing the climate: new approaches to rationality, power and politics. Cambridge University Press, Cambridge, UK. http://dx.doi.org/10.1017/ $\underline{\text { CBO9781107110069.015 }}$

Lövbrand, E., and J. Stripple. 2011. Making climate change governable: accounting for carbon as sinks, credits and personal budgets. Critical Policy Studies 5:187-200. http://dx.doi. org/10.1080/19460171.2011.576531

Lubell, M., G. Robins, and P. Wang. 2014. Network structure and institutional complexity in an ecology of water management games. Ecology and Society 19(4):23. http://dx.doi.org/10.5751/ ES-06880-190423

Lyster, R. 2011. REDD+, transparency, participation and resource rights: the role of law. Environmental Science and Policy 14:118-126. http://dx.doi.org/10.1016/j.envsci.2010.11.008

Mexico. 2010. Readiness Preparation Proposal (R-PP). Forest Carbon Partnership Facility. [online] URL: http://www. forestcarbonpartnership.org/sites/forestcarbonpartnership.org/files/ Documents/PDF/Mar2010/Mexico_120211_R-PP_Template_with disclaimer.pdf

Mexico. 2013. Emission Reductions Program Ideanote (ER-PIN). Forest Carbon Partnership Facility. [online] URL: https://www. forestcarbonpartnership.org/sites/fcp/files/2014/February/Mexico $\%$ 20ER-PIN $\% 20 \mathrm{CF} \%$ 20English.pdf

Mexico. 2016. Country Progress Sheet. Forest Carbon Partnership Facility. [online] URL: http://www.forestcarbonpartnership. org/sites/fcp/files/2017/Sep/FCPF $\% 20$ Country $\% 20$ Progress $\%$ 20Reporting $\% 20$ Template updatedMX.pdf

McDermott, C. L., H. van Asselt, C. Streck, S. Assembe Mvondo, A. E. Duchelle, C. Haug, D. Humphreys, M. Mulyani, C. Shekhar Silori, R. Suzuki, F. Zelli, S. Frick, M. Lentini, H. Luintel, and C. Salimon. 2012. Governance for REDD+, forest management and biodiversity: existing approaches and future options. Pages 115-137 in J. A. Parrotta, C. Wildburger, and S. Mansourian, editors. Third Assessment Report of the Global Expert Panel on
Biodiversity, Forest Management and REDD+. International Union of Forest Research Organizations, Vienna, Austria.

Milne, S., M. Milne, F. Nurfatriani, and L. Tacconi. 2016. How is global climate policy interpreted on the ground? Insights from the analysis of local discourses about forest management and REDD+ in Indonesia. Ecology and Society 21(2):6. http://dx.doi. org/10.5751/ES-08363-210206

Mohren, G. M. J., H. Hasenauer, M. Köhl, and G.-J. Nabuurs. 2012. Forest inventories for carbon change assessments. Current Opinion in Environmental Sustainability 4:686-695. http://dx.doi. org/10.1016/j.cosust.2012.10.002

Morales-Barquero, L., M. Skutsch, E. J. Jardel-Peláez, A. Ghilardi, C. Kleinn, and J. R. Healey. 2014. Operationalizing the definition of forest degradation for REDD+, with application to Mexico. Forests 5:1653-1681. http://dx.doi.org/10.3390/f5071653

Morse, J. C., and R. O. Keohane. 2014. Contested multilateralism. Review of International Organizations 9:385-412. http://dx.doi. org/10.1007/s11558-014-9188-2

Neumann, I. B. 2002. Returning practice to the linguistic turn: the case of diplomacy. Millennium 31:627-651. http://dx.doi. org/10.1177/03058298020310031201

Nielsen, T. D. 2014. The role of discourses in governing forests to combat climate change. International Environmental Agreements 14:265-280. http://dx.doi.org/10.1007/s10784-013-9223-4

Nigeria. 2013. Readiness Preparation Proposal ( $R-P P$ ). Forest Carbon Partnership Facility. [online] URL: http://www. forestcarbonpartnership.org/sites/fcp/files/2013/Nov2013/Nigeria $\%$ 20REDD $\% 2 B \% 20$ R-PP $\% 20$ November_2013\%5B1\%5D_Final.pdf

Nigeria. 2014. Readiness Preparation Proposal ( $R-P P)$. Forest Carbon Partnership Facility. [online] URL: http://www. forestcarbonpartnership.org/sites/fcp/files/2014/september/Nigeria $\%$ 20REDD $\% 20$ R-PP final $\% 20 \% 205 \% 20$ Aug $\% 202014$.pdf

Nigeria. 2017. Country Progress Sheet. Forest Carbon Partnership Facility. [online] URL: http://www.forestcarbonpartnership. org/sites/fcp/files/2016/Aug/Aug_2016 FCPF $\% 20$ REDD $\% 20$ Country $\%$ 20Progress $\% 20$ Report $\% 20 \% 2$ B.pdf

Ochieng, R. M., I. J. Visseren-Hamakers, B. Arts, M. Brockhaus, and M. Herold. 2016a. Institutional effectiveness of REDD+ MRV: countries progress in implementing technical guidelines and good governance requirements. Environmental Science and Policy 61:42-52. http://dx.doi.org/10.1016/j.envsci.2016.03.018

Ochieng, R. M., I. J. Visseren-Hamakers, M. Brockhaus, L. F. Kowler, M. Herold, and B. Arts. 2016b. Historical development of institutional arrangements for forest monitoring and REDD+ MRV in Peru: discursive-institutionalist perspectives. Forest Policy and Economics 71:52-59. http://dx.doi.org/10.1016/j. forpol.2016.07.007

Paraguay. 2015. Revised Readiness Preparation Proposal ( R-PP). Forest Carbon Partnership Facility. [online] URL: http://www. forestcarbonpartnership.org/sites/fcp/files/2015/May/RPP\%20Paraguay $\%$ 20rev\%20090614 English March23\%202015.pdf

Paraguay. 2017. Country Progress Sheet. Forest Carbon Partnership Facility. [online] URL: http://www.forestcarbonpartnership. 
org/sites/fcp/files/2017/July/Paraguay $\% 20 \mathrm{FCPF} \% 20 \mathrm{REDD} \%$ 20Readiness $\%$ 20Progress $\% 20$ Sheet julio $\% 202017$.pdf

Penman, J., M. Gytarsky, T. Hiraishi, T. Krug, D. Kruger, R. Pipatti, L. Buendia, K. Miwa, T. Ngara, K. Tanabe, and F. Wagner, editors. 2003. Good practice guidance for land use, landuse change and forestry. Institute for Global Environmental Strategies, Hayama, Japan. [online] URL: http://www.ipcc-nggip. iges.or.jp/public/gpglulucf/gpglulucf files/GPG LULUCF FULL. pdf

Peru. 2013. Revised Readiness Preparation Proposal (R-PP). Forest Carbon Partnership Facility. [online] URL: http://www. forestcarbonpartnership.org/sites/fcp/files/2014/February/R-PP $\%$ 20Perú $\% 20$ Final $\% 20$ Dec $\% 202013$-RESALTADO.pdf

Peru. 2014. Emission Reductions Program Idea note (ER-PIN). Forest Carbon Partnership Facility. [online] URL: https://www. forestcarbonpartnership.org/sites/fcp/files/2014/september/PERU_ERPIN Sept.\%2012.2014.pdf

Peru. 2015. Country Progress Sheet. Forest Carbon Partnership Facility. [online] URL: http://www.forestcarbonpartnership.org/ sites/fcp/files/2015/September/FCPF_August2015_Peru\%20updated. pdf

Raustiala, K., and D. G. Victor. 2004. The regime complex for plant genetic resources. International Organization 58:277-309. http://dx.doi.org/10.1017/S0020818304582036

Roe, E. 1994. Narrative policy analysis: theory and practice. Duke University Press, Durham, North Carolina, USA. http://dx.doi. org/10.1215/9780822381891

Romijn, E., M. Herold, L. Kooistra, D. Murdiyarso, and L. Verchot. 2012. Assessing capacities of non-Annex I countries for national forest monitoring in the context of REDD+. Environmental Science and Policy 19-20:33-48. http://dx.doi. org/10.1016/j.envsci.2012.01.005

Runk, J. V., G. O. Negría, L. P. Conquista, G. M. Peña, F. P. Cheucarama, and Y. C. Chiripua. 2010. Landscapes, legibility, and conservation planning: multiple representations of forest use in Panama. Conservation Letters 3:167-176. http://dx.doi. org/10.1111/j.1755-263X.2009.00093.X

Savaresi, A. 2013. REDD+ and human rights: addressing synergies between international regimes. Ecology and Society 18 (3):5. http://dx.doi.org/10.5751/ES-05549-180305

Schmidt, V. A. 2008. Discursive institutionalism: the explanatory power of ideas and discourse. Annual Review of Political Science 11:303-326. http://dx.doi.org/10.1146/annurev.polisci.11.060606.135342

Schmidt, V. A. 2017. Theorizing ideas and discourse in political science: intersubjectivity, neo-institutionalisms, and the power of ideas. Critical Review 29:248-263. http://dx.doi.org/10.1080/089$\underline{13811.2017 .1366665}$

Schroeder, H., and C. McDermott. 2014. Beyond carbon: enabling justice and equity in REDD+ across levels of governance. Ecology and Society 19(1):31. http://dx.doi. org/10.5751/ES-06537-190131

Stephan, B., D. Rothe, and C. Methmann. 2014. Third side of the coin: hegemony and governmentality in global climate politics.
Pages 59-76 in J. Striple and H. Bulkeley, editors. Governing the climate: new approaches to rationality, power and politics. Cambridge University Press, Cambridge, UK. http://dx.doi. org/10.1017/CBO9781107110069.007

Sterk, W., C. Arens, N. Kreibisch, F. Mersmann, and T. Wehnert. 2012. Sands are running out for climate protection: the Doha climate conference once again saves the UN climate process while real climate action is shelved for later. Wuppertal Institute for Climate, Environment and Energy, Wuppertal, Germany.

Stern, N. 2007. The economics of climate change. The Stern review. Cambridge University Press, Cambridge, UK. http://dx.doi. org/10.1017/CBO9780511817434

Thompson, M. C., M. Baruah, and E. R. Carr. 2011. Seeing REDD+ as a project of environmental governance. Environmental Science and Policy 14:100-110. http://dx.doi. org/10.1016/j.envsci.2010.11.006

UN-REDD. 2012. UN-REDD Programme Social and Environmental Principles and Criteria. UN-REDD Programme Eighth Policy Board Meeting. Doc. No. UNREDD/PB8/2012/ V/1. UN-REDD Programme, Geneva, Switzerland.

UN-REDD. 2013a. National forest monitoring systems: monitoring and measurement, reporting and verification $(M \&$ $M R V$ ) in the context of REDD+ activities. FAO, Rome, Italy. [online] URL: http://www.fao.org/3/a-bc395e.pdf

UN-REDD. 2013b. REDD+ in a green economy. Global Symposium Report. UN-REDD Programme, Geneva, Switzerland. [online] URL: http://www.unredd.net/documents/global-programme-191/ redd-and-the-green-economy-1294/global-symposium-redd-in-agreen-economy-3180/10815-redd-and-ge-symposiumreport-13august-10815.html

van Asselt, H. 2014. The fragmentation of global climate governance: consequences and management of regime interaction. Edward Elgar, Cheltenham, UK. http://dx.doi.org/10.4337/9781782544982

Van de Graaf, T. 2013. Fragmentation in global energy governance: explaining the creation of IRENA. Global Environmental Politics 13:14-33. http://dx.doi.org/10.1162/ GLEP_a_00181

Viet Nam. 2011. Readiness Preparation Proposal ( $R-P P)$. Forest Carbon Partnership Facility. [online] URL. https://www. forestcarbonpartnership.org/sites/forestcarbonpartnership.org/files/ Documents/PDF/Nov2011/Viet $\% 20$ Nam $\% 20$ R-PP Revised $\% 2018 \%$ 20November2011.pdf

Viet Nam. 2014. Emission Reductions Program Idea note (ER$P I N)$. Forest Carbon Partnership Facility. [online] URL: http:// www.forestcarbonpartnership.org/sites/fcp/files/2014/May/Vietnam $\%$ 20ER-PIN $\% 20$ May $\% 2026 . p d f$

Viet Nam. 2017. Country Progress Sheet. Forest Carbon Partnership Facility. [online] URL: http://www.forestcarbonpartnership. org/sites/fcp/files/2017/July/VN $\% 20$ FCPF $\% 20$ Country $\% 20$ Progress $\%$ 20Report $\% 20$ July $\% 2014 \% 202017$ FINAL.pdf

Visseren-Hamakers, I. J., C. McDermott, M. J. Vijge, and B. Cashore. 2012. Trade-offs, co-benefits and safeguards: current debates on the breadth of REDD+. Current Opinion in 
Environmental Sustainability 4:646-653. http://dx.doi.org/10.1016/ j.cosust.2012.10.005

Wagenaar, H. 2011 Meaning in action: interpretation and dialogue in policy analysis. M. E. Sharpe, London, UK.

Wagenaar, H., and S. D. N. Cook. 2003. Understanding policy practices: action, dialectic and deliberation in policy analysis. Pages 139-171 in M. A. Hajer and H. Wagenaar, editors. Deliberative policy analysis: understanding governance in the network society. Cambridge University Press, Cambridge, UK. http://dx.doi.org/10.1017/CBO9780511490934.007

Wallbott, L. 2014. Indigenous peoples in UN REDD+ negotiations: "importing power" and lobbying for rights through discursive interplay management. Ecology and Society 19(1):21. http://dx.doi.org/10.5751/ES-06111-190121

World Wide Fund for Nature (WWF). 2010. MRV of REDD+ safeguards. Ensuring effective REDD+ with environmental and social co-benefits and strengthened governance. World Wide Fund for Nature, Gland, Switzerland.

Yanow, D. 1996. How does a policy mean? Interpreting policy and organizational actions. Georgetown University Press, Washington, D.C., USA.

Zürn, M. 2018. A theory of global governance: authority, legitimacy, and contestation. Oxford University Press, Oxford, UK. http://dx.doi.org/10.1093/oso/9780198819974.001.0001

Zürn, M., and B. Faude. 2013. On fragmentation, differentiation, and coordination. Global Environmental Politics 13:119-130. http://dx.doi.org/10.1162/GLEP a 00186 